\title{
THE FALSE PROMISE OF COOPERATION IN THE JORDAN RIVER: STATE POLICIES AND DETERMINANTS
}

\author{
Z. Muchie
}

\author{
Ambo University \\ 19, Ambo, Ethiopia
}

\begin{abstract}
The study examines the false promise of cooperation in the Jordan River basin through the prism of state policies and determinants. The study is underpinned by the significance of pivotal riparian states. Based on their preeminence in determining the course of cooperation, the study considers Israel, Jordan and Palestine as pivotal riparian states. In terms of research methodology, qualitative approach was used. The study identified that domestic politics, regional dynamics and international water regimes are major determinant factors making cooperation to be a fantasy. Israel's doctrine of exceptionalism both in the sense of statehood and government type and the reciprocated denial of co-basin states in this regard are domestic political factors that impede the course cooperative events. Israel's geopolitical calculations via territorial expansion alongside of the Jordan River affect the cooperative milieu. The mere existence of water regimes either in the form of legal agreements or institutional attempts, does not bring effective cooperation. The finding of study shows that, domestic politics, regional dynamics and international water regimes are indeed determinant factors for the cooperative and conflictive nature of water sharing in the basin. The level of their impact however is neither equal nor constant. Importantly, these three factors affect and condition one another.
\end{abstract}

Key words: Jordan River, Cooperation, Domestic Politics, Regional Dynamics, Water Regimes, Pivotal States

\section{INTRODUCTION}

Water is a life in itself. Not only is the human community, all lives on the earth are dependent upon water for their very survival. However, water is unevenly distributed. Due to the disparity between supply and demand, control over and the governance thereof has become the keystone of the contemporary regional and international politics. Trans-boundary Rivers in this regard are signposts for such a deadlock. In the last centuries, there have been many inter-state water disputes, if not outright wars. The conflict between Pakistan and India over the Ganges River since 1951-1971 due to India's decision to construct the Farakka barrage, similar skirmish between Bangladesh and India soon after Bangladesh has become independent in 1971 from Pakistan, India's dispute with Nepal, the conflict between Turkey, Syria and Iraq over the Tigris-Euphrates Rivers and conflicts over the Nile river were best instances. The Jordan River is not

\section{(C) Muchie Z., 2019.}

(c) () This work is licensed under a Creative Commons Attribution 4.0 International License https://creativecommons.org/licenses/by/4.0/ 
exceptional to this trend. Conflicts over water are emanated from dynamics of domestic political factors, geopolitical calculations and the existence of flimsy water regimes governing the basin states. This paper is aimed at analyzing the false promise of cooperation in the Jordan River from the perspectives of domestic political dynamics, geopolitical factors and weak water regimes between pivotal riparian states of the basin.

\section{DOMESTIC POLITICAL FACTORS}

\section{The Israeli-Palestinian relation: identity as a political factor}

Perhaps the most complicated issue in the Israeli-Palestinian protracted conflict which thwarted the story of cooperation in the region is politicized identity. Most important in this regard is Israel's doctrine of exceptionalism. Protected by the baneful language of exceptionalism, Israel claims the right to mangle millions of lives, to persist in violence, start new wars, and, more recently, to threaten its neighbors through military power. The ideological aim of Israelis exceptionalism has been intentionally orchestrated and attained by impresarios. It has been promoted by both the political figures and the entire community. Israel's exceptionalism has mainly been drawn based on four principal perspectives. The first is the doctrine of chosen-ness [20. P. 172]. Israel's of sense of inherent exceptionalism was advocated by leaders even before its existence. This has been formally confirmed in 1950's through the secular expression of David Ben-Gurion, the founding father of modern Israel, as "We are perhaps the only "nonconformist' people in the world.... We do not fit the general pattern of humanity: Others say because we are flawed. I think [it is] because the general pattern is flawed, and we neither accept it nor adapt to...". This illustrated how such deep-rooted religious perceptions of exceptionalism were incorporated into the modern secular-nationalist creed of Israelis and thwarted its relationship with its Arab counterparts. The sense of inherent exceptionalism, which emanates from the perception of chosen-ness, also includes the belief that the Jews would become a "light unto the nations" or a beacon to the world [30. P. 411].

The biblical doctrine of chosen-ness was enough to clinch the validity of Zionist claims to Palestine. The doctrine of chosen-ness invokes the divine right of the Jewish people to nullify the historical and legal rights of Palestinians to their homeland. Implicitly, this gave the long-suffering Jews the right to expel or exterminate the Palestinians if they do not recognize the superior Jewish rights to their land [1. P. 6]. This chosen-ness gave the Zionist leaders incentive to convince the Jewish and Christian majority that seizing Palestine is not a theft rather Palestine is a promised land from God and He made it an eternal inheritance to the Jews. Thus, establishing the home in Palestine of the Jewish majority by depriving the Palestinians and by giving little or no attention to the existence of Arabs in Palestine was the main task of Zionism. This has become a reality since its creation in 1948.

The second perspective that Israelis exceptionalism has been based is its perception of itself as a "villa in the jungle", a state surrounded by Muslim enemy Arab states [7. P. 49]. To this end, Israel considered itself as uniquely vulnerable country in the Middle East. In order to secure itself against these unique threats to its existence, 
Israel claims exemption from the demands of international law. Accordingly, Israel used its attribute of vulnerability as a means of territorial and geostrategic extractions. This implies that Israelis national security is exceptional as measured by geostrategic elements. The third source of exceptionalism is that Israel is the only democratic state in the Middle East. It believes that it is Israel alone that holds up the ideal freedom in the ignorant corner of the Middle East, held in the vise-grip of monarchs and dictators. Similarly, Israel draws attention to its incredible growth since 1948, its standard of living and technology which make it an outlier, an exceptional society in the Middle East [7. P. 56]. By considering itself as the only democratic state, it has made the claim to singularity by locating itself in the Middle East. It uses geography to conceal the fact that it is a European outpost in the Middle East, a colonial-settler state that has continued to draw upon the financial resources, skills and technology of the most advanced western societies. The fourth source of Israelis exceptionalism exemplifies its achievements and some of these do appear exceptional at first sight to build the self-esteem of the group and win support for Israel in the west. It also serves to justify ex post facto, the removal of the inferior Palestinians by the superior Jews with its formidable strategic patron, the US [19. P. 9].

All these exceptional traits, particularly the perception of vulnerability, leads Israel to view its foreign relation from the prism of realism that "might is right." Thus, its insight of itself as a regional superpower that views its relation with the Palestinians in particular and the wider Arab world in general in terms of a zero-sum game appears to negate, a priori, any substantive multilateral cooperation with its neighbors on the whole range of security issues facing the Middle East. Accordingly, Israel's foreign policy has been explained based on the old mantra that Israel has no foreign policy, but only a stand by defense force policy towards its immediate Arab neighbors [21. P. 115]. The Arab's hateful expression of Israel as, "a thorn in their fresh," is the other dimensions that exacerbate the level of tension between riparian states of the river. Therefore, Israeli's sense of exceptionalism as well as mutual siege mentality towards one another has obstructed the essence of cooperation over the scarce water resource. Generally, the Israeli society and its subsequent leaders are convinced that the Jewish and the Israeli people, their historical experience and security problems they face are exceptional which rest on the domesticated cultural, historical and geostrategic foundations.

The relation of Israel with Jordan is not exceptional to this trend. They rather outlasted a very byzantine relationship. The question of national identity has put a benchmark on their relations. Conflict between Arabic-Islamism and Jewish-Zionism has persisted for several centuries. Religion and nationality are pillars of identity formations. Seen it from nationalistic view, both states have tried to form their own nation state within one national identity. Jordan for instance, has tried to create a single Jordanian nation having Jordanian identity under the umbrella of Arab-Islamic ideology. Ethnically, Jordan is an Arab state which greatly influenced by Arabic nationalism. The major objective of the Arab nationalism or the so-called pan-Arabism is forming a unified Arab state that demolishes and destroys the Jewish community from the region. Religiously, Jordan is an Arab-Islamic state whereas Israel is a Judaic dominated Jewish state. The most contentious issue in relation to religion is the question of Jerusalem. It 
is clear that Jerusalem is the center of three major religions; Judaism, Christianity and Islam, all of which were from the same ancestor, Abraham. Jerusalem has a special meaning in each religious doctrine. It is said to be Yerushaláyim in Hebrew. According to the Jews, Jerusalem is a Holy land that was mentioned for more than 154 times as Zion. In the beginning, Jerusalem was given for Abraham, the ancestor of the Jews through his son Isaac, from the almighty and gradually, it has come to be the center of Isaac and his sons, Esau and Jacob and later on to David and his son Solomon. Accordingly, Solomon built the first and the second temples and put in Jerusalem at Bethlehem. Consequently, as it has stated under many chapters of (II Samuel, Kings and Psalm), Jerusalem has been given as the religious capital of the Jewish through its ancestors (the Holy Bible). On the other hand, the city of Jerusalem is known as "Al-Quds" or "Baitul-Maqdis" in the Arabic terminologies. Alike the Jews, Muslims acknowledged Abraham as the ancestor of Muslims through his son Ishmael who is the father of Muslims. Abraham, the grandfather, has given Jerusalem for his elder son Ishmael as he has done unto Isaac. Therefore, since Ishmael on, Jerusalem has become the third Qibla for Muslims next to Mecca and Medina. Prophet Muhammad saw a vision through the miracle of angle Gabriel about the third mosque; Al-Aqsa, in Jerusalem (Qur'an 2: 142-44). Thus, Muslims have a deep devotion and spiritual connection to Jerusalem.

The other issue that prolonged warlike relation in relation to religion is the issue of the Jordan River. All religions took the river as a source of salvation of the Soul. The Israelites referring to Joshua, argued that God has pointed us to cross the Jordan River while the priests carrying the Ark of the Covenant would step into the Jordan and when their soles of the feet rests in the water (Joshua 3: 13). Thus, all the events in and around the Jordan River and the Ark of the Covenants are basic elements of the salvation of the soul. They added that as it is clearly stated under the Gospels, God himself was baptized in the Jordan River and ordered us to follow what he has done. Thus, the spiritual significance of the river for all Regions is indisputable. However, religion is very much politicized and served as a means of controlling strategic sites for political consumption which gnarled the spirit of cooperation over the scarce resource, water.

Even though the Palestinians and Jordanians are from the same gene, Arabic, their relation has never been based on amity rather was full of tensions. It was because of the fact that king Abdullah's intention of controlling the Arab-Palestinians and the annexation of the west bank as a province of Jordan. Being annoyed by the deeds of the king, the Palestinians assassinated the king in 1951. Not only this but also the Palestinians were very much annoyed by the king's secret talk with the Israelites. In 1964, the Arab league formed the Palestinian liberation organization (PLO) and in 1970, war broke out between the PLO and the Jordanians which was known as the Black September. Jordan has received assistance from Israel and defeated the PLO. Consequently, this war was a turning point for the revival of the Jordanian identity but the Palestinians are still in exile [14. P. 2-3]. Generally, politicized identity as a domestic political factor has smeared a soot on their relations which made the very culture of cooperation to be a fantasy. 


\section{GEO-STRATEGICAL FACTORS}

\section{Israeli-Palestine relation: geopolitical factors}

From its very existence, Israel is cautious of two basic and mutually interdependent processes that would determine its future status in the Middle East. The first was geopolitical calculations which had to do with the need to provide security for the fledgling state from external threats. This included not only threats to its existence, but also threats to the economic well-being of the population and the capacity for future growth through the absorption of large segments of the Jewish Diaspora. Water issues were central to Israel's geopolitical considerations, and the earlier British and Zionist desire to control the maximum number of possible water sources ultimately result in the demarcation of what would, in 1948, become Israel's northern and northeastern border. The northeastern border would later be revised through military action in 1967 brought on, in part, as a result of threats to Israel's water supply. Hence the need to secure water resources played a crucial role in Israel's geopolitical calculus with respect to its border with Syria over the Golan height, with Palestine over the Gaza Strip, east Jerusalem and West Bank, with Egypt over the Sinai Peninsula, with Jordan over the Yarmuk River and the Lebanese as well.

The second basic process that Israel has insisted on was that of state and society building. Here too, water was critical since the absorption of Jewish immigration and the creation of a Jewish demographic presence in as much of Palestine as possible was a necessary prerequisite for achieving statehood. Once the state came into being, it became necessary to absorb large numbers of immigrants from Europe and the Middle East and to strengthen Israel's demographic presence in the arid southern Negev region. This meant that water would have to be transported southwards in order to make largescale settlements in that part of the country a reality. Water was also needed to develop Israel's agricultural enterprises which, ideologically and economically, were of crucial importance in the pre-state and early-state periods (owing in part to the lack of a significant industrial base). Hence, water played a central role in the economic and demographic development of Israel and in matters relating to borders with riparian states of the basin. Frequently, geopolitical and state-building elements overlapped when it came to the water issues. Hence, spreading the population and the partial de-urbanization of Israel in the country's early years were seen as necessary for both geopolitical and state-building reasons and were dependent to a great extent on access to water; the Jordan River. The continued need to manage and safeguard water resources, as well as the growing need for additional water, is likely to smear soot events in Israel and its immediate neighbors for the foreseeable future and have an important impact, as they have had thus far, on future Israeli-Arab peace negotiations which undermined the spirit of cooperation.

Geography and politics are deeply intertwined in Israel, and the country's strategic culture, possible to say its existence, is profoundly shaped by geopolitics. As has been explained above, Israel perceived itself as a small, unique and regionally isolated country surrounded by potential enemies which do not formally recognize its existence and thereby viewed its own geo-strategic environment as hostile, unpredictable, volatile, 
and replete with dangers. As a result of this acute perception of vulnerability as well as history of existence, Israel has developed a 'siege mentality' alongside a sense of being under constant threat [34. P. 42]. Thus, the notions of geopolitical vulnerability and regional isolation are crucial to the country's unambiguously realist foreign and security policy established based on realist hard-power politics that engulfed all alternative ends of negotiating remarks [7. P. 50]. Israelis geo-strategic insight is based on the intensive and extensive view of the threat it has faced in the past and will face in the years to come. Because of this reason, most Arab states are seen by Israel as the actual coalitions seeking Israel's destruction or truncation. Israel believed that a single defeat would destroy the state and it would face future endless war with its neighbors. In this regard, Israelis geopolitical strategy is the deterrence of Arab hostility and waging a clear-cut defeat of the enemy through the expansion of territorial influence if deterrence fails [6. P. 5].

Territorial expansion has been taken as a national security issue in Israel. During the Six-Day War of 1967, Israel has defeated the allied forces of Egypt, Jordan, Syria and Lebanon and controlled the strategic sights of the Sinai, West Bank, Gaza, Jericho, east Jerusalem and the Golan height. While Sinai was returned to Egypt in the Camp David agreement of 1979, all the remaining strategic places are still under its control [23. P. 10]. Although agreements, concerning power transfer to the PLO over Gaza, West Bank, Jericho and east Jerusalem, was made by the leader of the two states in the interim DoP, it was suspended by Israel due to its geostrategic interest over the areas mentioned. The very recent plan that Israel has intended to build more than 2,000 houses in West Bank and Gaza for the Jewish émigrés including 30 homes in the flashpoint Palestinian-majority city of Hebron and the settlements of more than 25,000 Jews in the Negev desert that allowed Israel to divert significant amounts of water from the Jordan River and the shift of its capital from Tel-Aviv to Jerusalem is the case for the breach of the interim agreement ${ }^{1}$. It is because; Israel understood that divided cities are encapsulation of broader geopolitical conflicts due to different political, economic, spatial, and cultural dimensions. Jerusalem which played a dual role, politically and religiously, is a best example.

Israel has put four major geopolitical strategies for the control of the entire Jerusalem. (a), Territorial annexation i.e. annexing the east and west Jerusalem, (b), zoning and building regulation for curtailing the growth and expansion of the Palestinians, (c), residency and access restrictions; by separating Jerusalem from the west bank, access to the city was totally denied for the Palestinians and within Jerusalem, residency rights were restricted to the 1967census only, (d), demographic control. Therefore, the status of Jerusalem has put a negative benchmark in the relation of the Israelis and the Palestinians which in turn affect cooperation [18. P. 19].

The other geopolitical factor that impede the course of cooperation between riparian states in particular and the Arab-Israeli in general is the intervention of outside powers

${ }^{1}$ Israel to Build 2,000 houses in West Bank. The Hindu News. 11.10.2017. Available at: http://www.thehindu.com/todays-paper/tp-international/israel-to-build-2000-houses-in-west-bank/ article19836106.ece. Accessed: 11.10.2017. 
in the internal affairs of the basin states. The geostrategic importance of the region to its water and land transit and the vast petroleum and natural gas, are the magnets that now draw outside powers to the region. In their effort to gain competitive advantages in the region, these powers built and reinforced internal division between riparian states of the basin which in turn blocked their geopolitical integrations [9. P. 376]. Due to this, basin states allied themselves with superpowers to gain military support and financial aid. Thus, the involvement of superpowers in the internal affairs of riparian states has put a substantial impact on the peace process. For instance, the US assistance of Israel during the Six-Day War of 1967 and the Soviets patronage of the Arab armies during the Yom Kibur war of 1973, set major limitation to the peace process between basin states [6. P. 7]. It is clear that Israel is the first US aid receiving state in the Middle East followed by Egypt. The coming into power of Donald Trump has increased the likelihood of Israelis interaction with it and the regular flow of US aid to the former. During the reign of Obama's presidency, illegal settlements and constructions were strongly opposed mainly due to personal distastes between Obama and Netanyahu. However, this has been changed with the inauguration of Trump to the presidency and Trump showed Netanyahu the possibility of constructing houses in the occupied areas. To this end, Netanyahu said that "Tomorrow's world will be different - and it is very near and the plan will be succeed by changing the rule of the game"2. Besides, US recognition Jerusalem as the capital city of Israel and the shift of its embassy there is the case. Generally, so long as Israel does not accept the two-state solution that allowed the return of occupied territories to Palestine and the denial of the Palestinians to the one-state solution that allowed the domination of Israel over the Palestinians i.e. without accepting reciprocal sovereign recognition, peaceful relation, not to mention cooperation, between the two states is a castle in the sky.

\section{Israeli-Jordanian relation: geo-strategic importance}

Unlike other neighboring countries, the geo-strategic importance of Jordan has been both an advantage and liability for Israel. It is because on the one hand, the very position of Jordan and its usual involvement in the Palestinian issue has put Jordan at the locus of any solution to the Israeli-Palestinian conflict. On the other hand, the leading role of Jordan in the region next to Egypt has never been an easy threat for Israel. Conversely, the expansion and defensible policy of Israel concerning the Palestinians highly restrain and made Jordan's Palestinian policy at a particular reference to Israeli view [4. P. 23]. The raison d'état for the involvement of Jordan in the 1948 Israeli-Palestinians conflict which was largely known as the Arab-Israeli war in this regard, was strategic aspiration and territorial expansion. The motive of king Abdullah I at the time was expanding the territorial land mass of Jordan by annexing the West Bank and as much as possible the whole part of Palestine and thereby controlling the strategic site of West Bank, Gaza and east Jerusalem, which ought to be the a corpus separatum under the UN partition

2 Jeffay N. Four Reasons Why Israel Is Building New Homes in the West Bank. The Jewish Chronicle. 11.10.2017. Available at: https://www.thejc.com/news/israel/settlements-comment1.431247. Accessed: 11.10.2017. 
resolution. Though Jordan took part in the war, secret talks between Israel and its delegates was held regarding their future relations and the division of the West Bank. Accordingly, king Abdullah I signed an armistice agreement with Israel in 1949 but he was assassinated by the Palestinians at Jerusalem in 1951 due to his peace negotiation with Israel. Since then, a secret deal between Israel and Jordan was suspended for a decade. The succeeding king of Jordan, King Hussein has followed the policy of appeasing strong Arab states and allied Jordan with them to initiate anti-Israeli stance. Tension has been persisted in the region. In 1967 war between the Arabs mainly, Jordan, Egypt and Syria on the one side and the Israeli's on the other has broken out for six days. The war was said to be the Six-Day War. This war was a turning point for the Israeli's which provided it with a spatial strategic asset. In the war, Israel has defeated the allied power of the Arab league and occupied the West Bank, Gaza, the Golan height, the Sinai Peninsula and east Jerusalem [15. P. 8; 37. P. 1; 38. P. 1]. Not only this but also the war gave Israel a major hydro-political alteration.

By controlling the West Bank, Israel took control of the West Bank aquifers that can produce one-third of its fresh water supply. With the control of the Golan height, Israel controlled most of the upper Jordan and expanded its sphere of influence to the northern part of the Yarmouk River and east of the Ghor canal. The Arab states having no choice to regain the land they lost in the war has turned their face towards round table negotiations. Accordingly, in 1979, Egypt had made a peace treaty with Israel on the issue of the Sinai Peninsula. As it has been clearly stated under article 1(2) of the treaty, Israel and Egypt agreed to terminate the state of war and establish peace between them and Israel also agreed to withdraw its armed forces and the civilians from the Sinai and thereby Egypt would recommence full sovereignty over the area.

The Jordanian-Israeli hydrological linkage is mainly established on the Yarmouk River which flows along the border of Jordan and the Israeli-held Golan and runs just $6.5 \mathrm{~km}$ south of Lake Tiberias. The Yarmouk River is the major source of water for Jordan compared to its usage by Israel in its Yarmouk triangle farming area. What makes the Yarmouk River an issue of contention between Jordan and Israel is because; it is the major tributary of the Jordan River. The other user of the Yarmouk river, but too minimal, is Syria. Accordingly, Jordan has fought to maintain the Yarmouk River water under its control and pursued construction of dam(s) on the river, but it was not realized due to its sporadic political affiliation with Syria and a low-key contact with Israel. After the war (1967), the secret talks between Jordan and Israel on issues of water has increased. Especially since 1970's, the Israeli's military assistance to King Hessian of Jordan in its [Jordan] conflict with the Palestinians which was known as "black September", has changed the attitude of the Jordanians towards amicable diplomatic relations [39. P. 99]. After the 1973 Arab-Israeli war which was known as Yom Kippur for the Israelites and the Ramadan for the Arabs, their secret talks were enormously developed. Since then, both sides achieved greater communication particularly on issues of water sharing with the mediation of US based on the Johnston plan of 1955 and 1963's Criddle mission. Despite the existence of misgivings and tensions on both sides regarding the issue of the Israeli's Yarmouk triangle, the communiqué between them was developed into an open negotiation after the Gulf war and the subsequent Madrid 
conference [8. P. 1]. Finally, it has been resulted in the signing of the peace treaty of 1994 between Jordan and Israel. As has been discussed in chapter three of this study, the 1994 peace treaty was a breakthrough in the Jordanian-Israeli relations. In the peace treaty, both sides recognized a right full allocation of water both from the Yarmouk and the Jordan Rivers. Though the issue of water outweighed the discussion, matters related to border demarcation, security, diplomatic and future interactions as regards to politics, economics and socio-cultural ties were part of the treaty. To sum, despite the existing challenges, cooperation on the equitable and reasonable sharing of water particularly since 1994 between Jordan and Israel is more apparent and recordable than other Arab States in the region.

\section{THE EXISTENCE OF FLIMSY WATER AGREEMENTS}

\section{The Sykes-Picot Agreement (1916)}

The Sykes Picot also called the Asian Minor Agreement (AMA) was a secret deal between Britain and France signed on March 1916 to define their mutually agreed sphere of influence in the region. The agreement provided Britain control over the coastal strip between the Mediterranean Sea and the river Jordan, upper Galilee, the Huleh Valley, Jordan, southern part of Iraq, and the port of Haifa and Acre [28. P. 476]. France got control over the southeastern part of Turkey, northern Iraq, Syria and Lebanon. Subsequent partitions were made on areas occupied by Ottoman Empire since the defeat of the Ottoman Empire in the WWI. Thus, the Ottoman Arab provinces outside of the Arabian Peninsula were divided as a British-France sphere of influence. An international administration zone was established for the Palestinians. However, France was dissatisfied with the partition since it provided all water bodies to Britain.

After the WWI in the Paris peace conference, Palestine, Transjordan, Syria and Lebanon were under the joint administration of Britain and French. Various proposals have been submitted by delegates from each side over the frontiers to be divided before a formal talk between France and Britain [25. P. 344]. The proposal submitted by the British political delegation claimed the sources of the Litani along the Mediterranean Sea to the curve in the Litani River to the streams flowing into the Jordan and those flowing east toward Damascus and the Yarmuk to be parts of the British sphere of influence and this frontier would allocate all the Jordan water to Palestine. Contrary to it, the military delegation of Britain wanted it to be parts of the northern parts of the river containing the river Zahrani to Mt. Lebanon for the closure of future strife with France in the Middle East. France opposed the proposal mainly because the proposal totally conceded all parts of Palestine, Armenia and Mosul to Britain. It thus breaches the Sykes-Picot agreement that Palestine was to be under a joint administration as an international zone. Still disagreements were there. Britain wanted to seize the whole part of the Yarmuk River and France was hesitated this plane. Thus, they compete over the whole partition of the Middle East. Consequently, France was keen to maintain control of territories under its mandate. Likewise, Britain insisted on controlling the most oil rich parts of Mosul and the trade routes including the Suez Canal [13. P. 700]. Generally, the agreement was meant for the benefit of the signatory states than easing fertile grounds for the cooperative management of the river water. 


\section{The Balfour Declaration}

The Balfour Declaration has for long been an issue of contention. No consensus has been made as to why it was made. While many traced it with the long term interest of Britain in the Middle East, others argued as it was a means to give the Zionists resided in Russia, a rationale for the fight alongside of the allies [24. P. 60]. In relation to this, Sykes said that "Nobody knows why the Balfour Declaration was made" [40. P. 4]. As the name implies, this was the declaration made by Balfour, a foreign secretary of Britain, in support for the establishment in Palestine of the national home for the Jewish community. In a letter sent to Rothschild, the leader of British Zionists federation, Balfour declared that the Zionists would have to become a state instead through establishing their home and define as a political entity. The declaration did not clearly mention for which Jew the national home would be established on the land of Palestine. Thus, it paved the way for the mass influx of those having a Jewish ancestral ship from different directions and forms a Zionist national movement in Middle East particularly in Palestine. Thus, the declaration was a tit-for-tat for what the Zionists wanted and what Britain needed in Middle East.

The Zionists at the time have a single motive, a national home in Middle East for the Jewish community. Britain on the other hand has a double-pronged long-term interest in the area, strategic considerations and long-term political interests. Britain saw its friendship with the Zionists, particularly the opposition of the later against France, as a best way to abrogate the Sykes-picot agreement of 1916 and to substitute some form of British control in the area. The Belfour declaration was a means of holding the Zionists as a convenient instrument to clout the French out of Palestine [16. P. 132]. Besides to this, Britain wanted to use the Jewish population as a military might against the Ottoman Empire in order to expand its sphere of influence in the Middle East. Though the declaration has hid the issue of water, territorial expansion by definition includes major water and water bodies. Therefore, it was a means of aggrandizing the interest of colonial powers other than easing cooperative spirits in the region in general and between the riparian states of the Jordan River in particular. Instead, it has laid the legacy of suspicion, threat and conflict for today's Middle East peace process [33. P. 1].

\section{The Eric Johnston Plan (1953-55)}

A special envoy, Eric Johnston, from the US was sent to negotiate an inclusive plan for the equitable allocation of the Jordan River and to surface the tension erupted between Israel and the Arab states of the basin [41. P. 536]. The plan was called the unified plan established based on the Tennessee Valley Authority (TVA) ${ }^{3}$. As a regional cooperative framework, the plan was made based on the needs and consumption of each state and the available resources mainly based on quantity than quality by ignoring the geographical borders separating them [26. P. 69]. Accordingly, each state explained their need and consumption level. Consequently, it has provided $400 \mathrm{MCM} / \mathrm{yr}$ to Israel,

3 A plan which was set up to address environmental, economic, and social challenges in a poor region of the United States during the 1930s. 
$720 \mathrm{MCM} / \mathrm{yr}$ to Jordan, $132 \mathrm{MCM} / \mathrm{yr}$ to Syria, and $35 \mathrm{MCM} / \mathrm{yr}$ to Lebanon [22. P. 164]. Put another way, Israel was allowed to use $40 \%$ of the water and the remaining $60 \%$ was reserved for a joint exploitation between Jordan, Syria and Lebanon [10. P. 219]. Besides, the plan favored Israel to use Lake Kinnert (Tiberias) as its storage capacity for the Jordan water and allowed the kingdom of Jordan to build a dam at Maqarin for the storage of the Yarmuk River with no reference to the Litani and other tributaries to the Jordan River [11. P. 259].

In fact, it was made to address two basic purposes. The first is to help Israel to be on its position and claim its recognition by the Arab states and secondly to resettle the Palestinian refugees on the Jordan valley. In such a way, both sides were agreed on the plan. The plan at its initial stage was successful particularly on the technical issues. Israel amongst others was cautious of the legal binding nature of the plan. However, it was not formally ratified by basin states though they accepted it as a Defacto water allocation (quota). Israel was cautious because Israel would no longer receive aid from America if rejected the unified plan in the one hand and America promised Israel $\$ 10$ million surplus food program [41. P. 541]. Notwithstanding its good attempt, all the intended objectives were remained rhetoric and the plan was no longer accepted by the Arab League of the basin ${ }^{4}$ [3. P. 24]. Two basic reasons determined the demise of the Johnston plan. The first was political ramification. The Arab league states in the basin claimed that accepting the water negotiation of Johnston and confirming the water right of Israel by implication means accepting and recognizing Israel as a state which none of them dreamed to be and where Israel was conceived by many as 'thorn in the fresh of the Arabs' [2. P. 263; 12. P. 124; 22. P. 165]. So, without surfacing the political arena and border issues between Israel and the Arab League referring Palestine; it would be absurd to negotiate over water.

The second was the distrust of the Arab League to America's tacit approach in the region. The League worried that using the good approach of its envoy; America would penetrate its economic relation over water particularly with Israel [10. P. 220]. Therefore, the Johnston's plan was abandoned in 1955 by contributing nil to the cooperative management of the river mainly because of the rejection of the Arab states of the basin attributing their nasty political relation with Israel. Following the failure of the Johnston plan however, otherwise bilateral agreements over the Jordan River have been concluded that embellish the existing spoiled tension.

\section{The 1993 Oslo Accord}

The persistent intifada of the Palestinians against Israel was the genesis of the Oslo accord. As early as 1970's and 1980's the issue of the future status of the state of Palestine and the occupied territories were highly debated [17. P. 67]. Tensions and warlike interactions were the day to day happenings between the two states. After lots of causalities from both sides, the Oslo accord also called an interim agreement was signed between Israel and the PLO on 13 September 1993. The agreement was an interim because it was limited for five years only. Letters that signify mutual recognition,

\footnotetext{
${ }^{4}$ States such as Syria, Palestine, Jordan, Lebanon and including Egypt.
} 
declaration of principles (DoP) on interim self-government arrangement, protocol on economic relations, the status of the Gaza strip and Jericho and agreements on preparatory transfer of power and responsibility were amongst the basic point being discussed [27. P. 486]. The major aim of the declaration was giving an everlasting solution to the strife between the two perturbing states. Consequently, as it has been clearly explained by Selby [36. P. 96] and the exchange of letters between the two leaders, it was meant for the fabrication of external bureaucracy in the name of transferring power from the Palestinian insiders to the PLO outsiders returning from Tunis. Besides, the agreement was not a comprehensive arrangement since it lacked the basic issues of strife, the status of Jerusalem, border and territorial issues, Jewish settlements in the lands of the Palestinians without considering what will be the future of the Palestinian refugees. These were the foremost concerns that the Palestinians were strived to be discussed. Rather, the agreement claimed that all these issues would be resolved within the five year interim period and Rabin; the then prime minister of Israel has made no assertion other than the recognition of PLO as the representatives of the Palestinians [17. P. 68]. The agreement identified water as the cardinal pathway for cooperation, but reluctantly mentioned the need for the establishment of the Palestinian Water Authority (PWA). Being reluctant, the agreement has vaguely and fuzzily referred the rights and allocations of water between the Israeli's and the Palestinians [35. P. 103]. Accordingly, the Oslo I was concluded with pledging Israel and dissatisfying the Palestinians and both of them have failed to secure what they have promised [32. P. 60].

Upon its failure to address those basic issues, an interim self-government over the areas of the Gaza Strip and the Jericho was signed in1995. This agreement was said to be the Oslo II [38. P. 26]. In the agreement, Israel agreed in principle to withdraw its military force and civilians from Gaza and Jericho areas. However, Israel refused the withdrawal of the settlers and Jerusalem was remained parts of Israel. What was the intention of Israel at the time was protection of Israeli's identity as a Jewish state under a secured environment [17. P. 69; 29. P. 26]. Israel knowingly agreed to the accord since these areas were dry lands that would not have significant effect on the water supply of the Israelis. The most important legacy of the Oslo II was the joint IsraeliPalestinian management of the west bank ground water resources [36. P. 103]. Thus, the Oslo accord has clearly marked the Palestinian's slow decline and made it a would be State.

\section{The Peace Treaty between Israel and Jordan (1994)}

The history of Israeli-Jordanian peace process has always been characterized by tensions because of the desire of securing ultimate share from the river on the one hand and the failure of Jordan to challenge anti-Israeli groups (pro-Palestinian and the Arab resistance to the recognition of the state of Israel) [22. P. 167]. Despite the quarrel in between however, the two states have started informal talks since the first Arab-Israeli war of 1948. The relation of the two states has been transformed into a formal and open negotiation after the 1991 Gulf war and the subsequent Madrid conference [8. P. 1]. After years of strife, the two states signed a peace treaty on 26 Oc- 
tober 1994. In the treaty, border demarcations, security issues, diplomatic and future bilateral relations in terms of politics, economics and other related issue areas have been discussed. Refugee and displaced persons and religion were parts of the discussion. The main focus of the treaty was however water in particular reference to the Jordan and the Yarmuk Rivers for the achievement of a comprehensive and lasting peace in the settlement of water problems.

Though it is a bilateral treaty, it has been made within the principle of international water law and the Helsinki rules. The two states recognize the equitable and reasonable water allocation based on the internationally accepted principles, quotas and the set grounds for the joint management and protection of the quality of the river waters. Furthermore, their interaction over the management and fair allocation of water would lead them further regional integrations as to political, economic and socio-cultural aspects. Generally, despite its bilateral nature, it has paved the way for a cooperative management of the Jordan River and its main tributary, the Yarmuk. But it does not mean that it provides an everlasting solution to the basin. Mutual suspicion is continuing. From the very beginning, Jordan sought that the agreement must, among others, focused on strategic decisions; the factor that would turned the two states in particular and the region in general into intractable intimidations. However, by no means, Israel tolerates any agreement on strategic sights since it took its strategic position as a matter of security [31. P. 75]. Generally, the mere existence of water regimes either in the form of bilateral agreements or institutional attempts has contributed nothing for the existence of effective cooperation in the basin.

\section{CONCLUSION}

Governance of shared water resource has become one of the defining features of contemporary regional and international politics. This study focused on the governance of water in the Jordan River basin thereby analyzing the false promise of cooperation between riparian states. The study is underpinned by the significance of pivotal riparian states. In the context of this study, pivotal states refer to states with indispensable roles in determining the course of cooperation and conflict in the river. Based on their preeminence in economic, military and geo-strategy, the study considers Israel, Jordan and Palestine as pivotal states. Accordingly, the study found that domestic political dynamics in the pivotal riparian states affects the state of cooperation. Israel's exceptionalism both in the sense of statehood and government type and the reciprocal aversion and contemplation of Israel by Arab's as a thorn in their fresh in this regard are domestic political factors that made cooperation a mirage.

Geopolitical factors which can be expressed in terms of spatial power, mutual destabilization and global alignment are the other factors that affect cooperation in the basin. The mere existence of water regimes, either in the form of legal agreements or institutional attempts, doesn't create mutually cooperative milieu. In particular, the exclusionary nature of the agreements has created a climate of mutual mistrust and suspicion. This can be explained by two major factors, the nature of legal agreements and the asymmetrical power relation between pivotal states. Therefore, domestic politics, 
regional dynamics and international water regimes are indeed important variables in determining the cooperative dynamics of the basin. The level of their impact however is neither equal nor constant. Importantly, these three factors affect and condition one another.

\section{REFERENCES}

[1] Alam M. Israeli Exceptionalism: The Destabilizing Logic of Zionism. Palgrave and Macmillan; 2009. 274 p. DOI: 10.1057/9780230101371.

[2] Allan J. Hydro-Peace in the Middle East: Why No Water Wars? A Case Study of the Jordan River Basin. SAIS Review. 2002; Vol. XXII; 2: 255-272.

[3] Amery H. The Role of Water Resources in the Evolution of the Israeli-Lebanese Border. Geo Journal. 1998; Vol. 44; 1: 19-33.

[4] Barari H. Jordan and Israel: A Troubled Relationship in a Volatile Region. Friedrich-EbertStiftung Jordan \& Iraq; 2014. 152 p.

[5] Beaumont P. Dividing the Waters of the River Jordan: An Analysis of the 1994 Israel-Jordan Peace Treaty. International Journal of Water Resources Development. 1997; 13; 3: 415-424.

[6] Ben-Horin Y., Posen B. Israel's Strategic Doctrine, a Paper Prepared for the Director of the Net Assessment, Office of the Secretary of Defense. USA: RAND; 1981. Available from: https://www.rand.org/content/dam/rand/pubs/reports/2007/R2845.pdf. Accessed: 01.03.2019.

[7] Berti B. Israel: Seeking Stability, in Kristina Kausch (Ed.) Geopolitics and Democracy in the Middle East. Spain: FRIDE; 2015: 49-62.

[8] Caplan N., Eisenberg L. The Israel-Jordan Peace Treaty: Patterns of Negotiation, Problems of Implementation. Israel Affairs. 2003; Vol. 9; 3: 87-110.

[9] Cohen S. Geopolitics: The Geography of International Relations, 3rd ed. London: Rowman \& Littlefield; 2015. $491 \mathrm{p}$.

[10] Daoudy M. A Missed Chance for Peace: Israel and Syria's Negotiations over the Golan Heights. Journal of International Affairs. 2008; Vol. 61; 2: 215-234.

[11] Dellapenna J. et al. Hydro-Geographic Background to the Utilization of International Rivers in the Middle East. American Society of International Law. 1986; Vol. 80; 9-12: 250-267.

[12] Fathallah R. Water Disputes in the Middle East: An International Law Analysis of the IsraelJordan Peace Accord. Journal of Land Use \& Environmental Law. 1996; Vol. 12; 1: 119-151.

[13] Fitzgerald E. France's Middle Eastern Ambition, the Sykes-Picot Negotiations, and the Oil Fields of Mosul, 1915-1918. The Journal of Modern History. 1994; Vol. 66: 697-725.

[14] Gallets B. Black September and Identity Construction in Jordan. Journal of Georgetown University. 2015. DOI: 10.5339/messa.2015.12.

[15] Gat M. In Search of a Peace Settlement Egypt and Israel between the Wars, 1967-1973. New York: Palgrave Macmillan; 2012. 304 p.

[16] Gillon D. The Antecedents of the Balfour Declaration Middle Eastern Studies. 1969. Vol. 5; 2: $131-150$.

[17] Hassan Sh. Oslo Accords: The Genesis and Consequences for Palestine. Social Scientist. 2011; Vol. 39; 7/8: 65-72.

[18] Hasson Sh. The Israeli-Palestinian Conflict in Jerusalem: The Challenge of Transition. The Floersheimer Institute for Policy Studies Ltd. Israel; 2007. 166 p.

[19] Hinnebusch R. The International Politics of the Middle East. New York: Manchester University Press; 2003. $262 \mathrm{p}$.

[20] Inbar E. Jews, Jewishness and Israel's Foreign Policy. Jewish Political Studies Review. 1990; Vol. 2; 3: 165-183.

[21] Jones C. The Foreign Policy of Israel. Middle East International. 1990; Vol. 12; 6: 110-145.

[22] Kliot N. Water Resources and Conflict in the Middle East. London: Rutledge; 1994. 328 p.

[23] Krebs R. Israel's Bunker Mentality: How the Occupation is Destroying the Nation. Foreign Affairs. 2011; Vol. 90; 6: 10-18. 
[24] Levene M. The Balfour Declaration: A Case of Mistaken Identity. The English Historical Review. 1992; Vol. 107; 422: 54-77.

[25] Lewis B. The Middle East: A Brief History of the Last 2,000 Years. New York: Scribner; 1995. $448 \mathrm{p}$.

[26] Lung R. Nary a Drop to Drink: Water Stress Intensifies in Jordan River Basin. Harvard International Review. 1994; Vol. 16; 4: 68-69.

[27] Malanczuk P. Some Basic Aspects of the Agreements between Israel and the PLO from the Perspective of International Law. EJIL. 1996: 450 - 500.

[28] Mather Y. The Fall of the Ottoman Empire and Current Conflict in the Middle East. Critique. $2014 ; 42 ; 3: 471-485$.

[29] Matthews E. The Israel-Palestine Conflict: Parallel Discourses. London: Routledge; 2011. $276 \mathrm{p}$.

[30] Merom G. Israel's National Security and the Myth of Exceptionalism. Political Science Quarterly. 1999; Vol. 114; 3: 409-434.

[31] Nahar G. The Factors Affecting the Foreign Political Behaviors in Jordan on its Strategic Position in the Middle East, and Especially its Conflict and Peace Process with Israel during the 1990s. International Journal of Humanities and Social Science. 2013; Vol. 3; 4: 66-78.

[32] Perlmutter A. The Israel-PLO Accord Is Dead. Foreign Affairs. 1995; Vol. 74; 3: 59—68.

[33] Renton J. The Historiography of the Balfour Declaration: Toward a Multi-causal Framework. Journal of Israeli History. 1998; Vol. 19; 2: 109-128.

[34] Roberts S. Israeli Foreign Policy in Historical Perspective. World Affairs. 1972; Vol. 135; 1: $40-53$.

[35] Rosenthal E., Sabel R. Water and Diplomacy in the Jordan River Basin, Israel Journal of Foreign Affairs III. 2009; 2: 95-115.

[36] Selby J. Water, Power and Politics in the Middle East: The other Israeli-Palestinian Conflict. London: I.B. Tauris \& Co Ltd; 2003. 275 p.

[37] Sheffi N. Shifting Boundaries: The 1967 War in Israeli Children's Magazines. The Journal of Israeli History. 2009; Vol. 28; 2: 137-154.

[38] Shlaim A. The Oslo Accord. Journal of Palestine Studies. 1994; Vol. 23; 3: 24-40.

[39] Sosland J. Cooperating Rivals: The Riparian Politics of the Jordan River Basin. New York: State University of New York Press; 2007. 310 p.

[40] Sykes Ch. Crossroads to Israel, 1917-1948, 1st ed. London: Indiana University Press; 1965. 404 p.

[41] Wishart D. The Breakdown of the Johnston Negotiations over the Jordan Waters. Middle Eastern Studies. 1990; Vol. 26; 4: 536-546.

\title{
ЛОЖНОЕ ОБЕЩАНИЕ СОТРУДНИЧЕСТВА В БАССЕЙНЕ РЕКИ ИОРДАН: ДЕТЕРМИНАНТЫ ПОЛИТИКИ ГОСУДАРСТВ РЕГИОНА
}

\author{
3. Мучие \\ Университет Амбо \\ 19, Амбо, Эфиопия
}

Аннотация. В исследовании рассматриваются ложные перспективы сотрудничества в бассейне реки Иордан через призму государственной политики стран региона. Основываясь на их роли в определении курса потенциального сотрудничества, автор рассматривает Израиль, Иорданию и Палестину 
в качестве ключевых прибрежных государств. В качестве методологии исследования в статье использовался качественный подход. Израильская доктрина исключительности как в отношении государственности и типа правительства, так и в плане взаимного отрицания государств бассейна выступает в качестве внутриполитического фактора, препятствующего возможностям сотрудничества. Геополитические расчеты руководства Израиля на территориальную экспансию вдоль реки Иордан также радикально влияют на возможные условия сотрудничества. Само существование водных режимов либо в форме правовых соглашений, либо в форме институционализированных проектов не обеспечивает эффективного сотрудничества стран региона. Результаты исследования показывают, что внутренняя политика стран, региональная динамика и международные водные режимы являются определяющими факторами кооперативного или конфликтного характера совместного использования водных ресурсов в бассейне реки Иордан.

Ключевые слова: Река Иордания, сотрудничество, внутренняя политика, региональная динамика, водные режимы, ключевые государства

\section{Сведения об авторе:}

Зелалем Мучие - преподаватель департамента гражданственности и этических исследований, Университет Амбо (Эфиопия) (e-mail: muchiezelalem@gmail.com).

\section{Information about the author:}

Zelalem Muchie - Lecturer of Department of Civics and Ethical Studies, College of Social Sciences and Humanities, Ambo University (Ethiopia) (e-mail: muchiezelalem@gmail.com).

Статья поступила в редакцию 15.03.2019.

Received 15.03.2019.

\section{Для цитирования:}

Muchie Z. The False Promise of Cooperation in the Jordan River: State Policies and Determinants // Вестник Российского университета дружбы народов. Серия: Политология. 2019. Т. 21. № 2. C. 295 -310. DOI: 10.22363/2313-1438-2019-21-2-295-310.

\section{For citation:}

Muchie Z. The False Promise of Cooperation in the Jordan River: State Policies and Determinants. RUDN Journal of Political Science. 2019; 21(2): 295-310. DOI: 10.22363/2313-1438-2019-212-295-310. 